\title{
Brot úr sögu stungulyfja Með sérstöku tilliti til íslenskra aðstæðna
}

\section{Notkun stungulyfja}

Jóhannes F. Skaftason ${ }^{1}$

cand. pharm., áður lektor og Iyfsali

skafta@internet.is

Jakob Kristinsson ${ }^{2}$

cand. pharm., prófessor

jakobk@hi.is

Porkell

Jóhannesson ${ }^{2}$

dr. med., áđur prófessor

dr.thorkell@simnet.is

\section{Seinni hluti:} Stungulyf á Íslandi

- fyrri hlutinn birtist í febrúartölublađinu: Skaftason JF, Kristinsson J, Jóhannesson P. Brot úr sögu stungulyfja. Með sérstöku tilliti til íslenskra aðstæðna. Læknablaðið 2011; 97: 101-7.

Heimildalistinn er tölusettu miðað við báða hluta greinarinnar og sama gildir um myndefni.

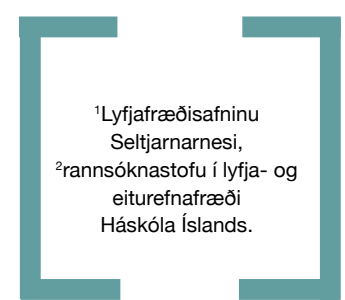

Fyrsta heimild á prenti um að morfínstungulyf hafi verið notað við skurðaðgerðir hér á landi virðist vera frá tímabilinu 1890-1895. Guðmundur Guðmundsson (1853-1946), læknir, skar upp sjúkling með kviðslit og klemmdan parm og gaf morfín í formi stungulyfs og „snafs” á undan aðgerðinni. ${ }^{41}$ Pessi unga heimild og pað að Sjúkrahús Reykjavíkur virðist ekki hafa átt lyfjadælur árið 1878 bendir eindregið til pess að lyfjadælur hafi að minnsta kosti ekki verið almenn eign lækna fyrr en kom fram undir lok 19. aldar. Um aldamótin 1900 virðist samt „sprauta og morfín“ vera orðið meðal parfapinga í læknatöskum. ${ }^{13}$ Ef til vill skýrist pessi „fátækt" af ummælum Vilmundar Jónssonar: „Allt fram á níunda tug aldarinnar, er ígerðarvarnir tóku loks að nema hér land, voru skurðaðgerðir íslenskra lækna með stökustu og strjálustu undantekningum einungis aðgerðir, sem nú myndu flokkast undir chirurgia minor í allra fábreyttasta formi. ${ }^{\text {"41 }}$ Pað parfnast hins vegar fyllri skýringar, að svo virðist sem enginn á Íslandi hafi á pessum árum pjáđst af „neuralgia“, líkt og í nálægum löndum og áður ræðir, og purft morfín í formi stungulyfs við verkjum. Eða voru Íslendingar bara látnir pola verki lyfjalaust?

Guðmundur Magnússon (1863-1924), síðar prófessor, kom til starfa hér á landi árið 1894 og við pað urðu tímamót í skurðlækningum á Íslandi. ${ }^{32,33}$ Svo virðist samt sem Guðmundur hafi fyrstu árin einkum fengist við tiltölulega einfaldar sullaveikisaðgerðir par sem verkjadeyfingar var ef til vill ekki pörf. Fjölbreyttari skurðaðgerðir (kviðslit, botnlangabólga, magaskurðir og fleira) virðast fyrst hafa komið til að marki um aldamótin og eftir раð. Vitað er að Guðmundur notaði morfín til innstungu við magaskurðaðgerð árið $1906^{41}$ og kókaín og kókaín-adrenalín við skurðaðgerðir árin 1903, 1905 og 1906. ${ }^{42}$ Skýrslur kennsluspítala Læknaskólans 1866-1911 (fyrst Sjúkrahús Reykjavíkur og frá 1902 St. Jósepsspítali (Landakotsspítali)) veita ótrúlega litlar upplýsingar um lyfjagjafir. ${ }^{42}$ Er engu líkara en skýrslurnar séu skrifaðar út frá skurðlæknissjónarmiði einu saman, par eð einu lyfin sem eitthvað virðast koma við sögu eru svæfingarlyf eða staðdeyfingarlyf. Petta

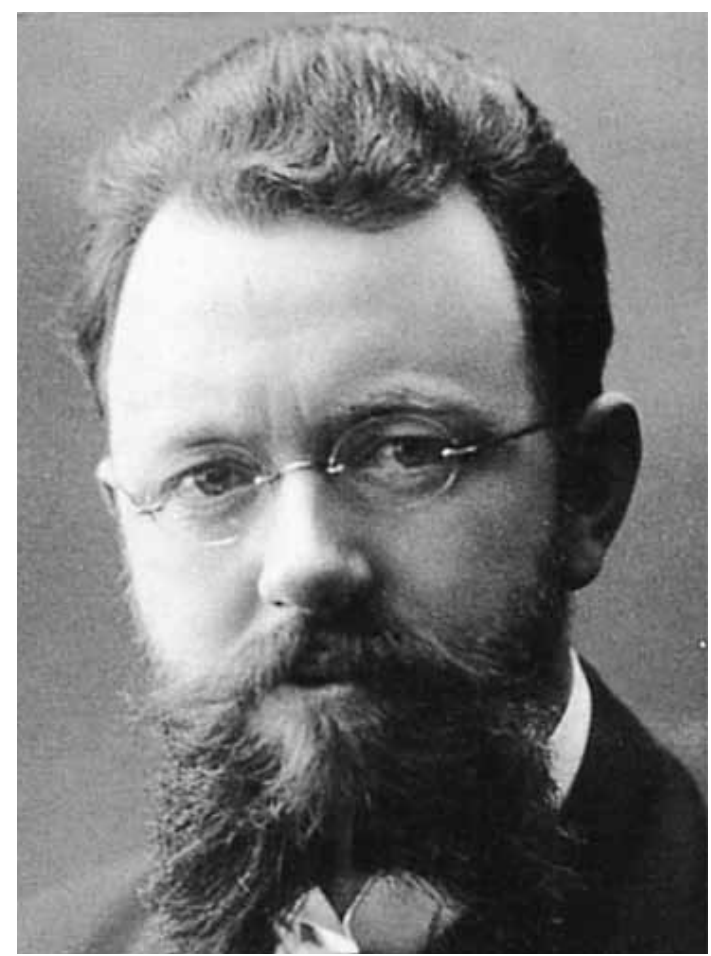

Mynd 8. Matthías Einarsson (1879-1948) starfaði á Landakotsspitala í meira en 40 ár frá 1905 að telja. Hann var brautryðjandi i notkun prókaíns (og yngri staðdeyfingarlyfja) til staðdeyfingar í stað kókaíns við skurðaðgerðir. Hann var meðal fyrstu íslenskra lækna til pess að vinna með mænudeyfingu og innleiða svæfingu mеð gjöf i æð. (Myndin er úr safni Lææknablaðsins.)

sama gildir og um síðari skýrslur ríkisspítala (Landspítali, Kleppsspítali, Vífilsstaðaspítali), að minnsta kosti langt fram eftir fjórða áratug 20. aldar. Ef til vill hefur ráđandi mönnum í læknastétt í pá daga pótt flest lyf sem gefin voru svo ómerkileg að ekki tæki pví að nefna pau! Frá hendi Matthíasar Einarssonar eru pó nokkru fyllri upplýsingar í ritgerðarformi í ársskýrslum Landakotsspítala árin 1934 og 1946.

Matthías kom til starfa á spítalanum árið 1905 (fyrst aðstoðarlæknir Guðmundar Magnússonar; varð yfirlæknir 1934 og til æviloka 1948 (mynd 8)). Af skrifum Matthíasar má ráða að hann hafi tekið að nota prókaínstungulyf við skurðaðgerðir (og síðar einnig yngri staðdeyfingarlyf) með adrenalíni a.m. Matthías segir árið 1934, að síðustu 15-20 árin hafi notagildi staðdeyfingarlyfja við skurðaðgerðir mjög farið vaxandi. Sama ár hóf hann ennfremur að nota mænudeyfingu við 


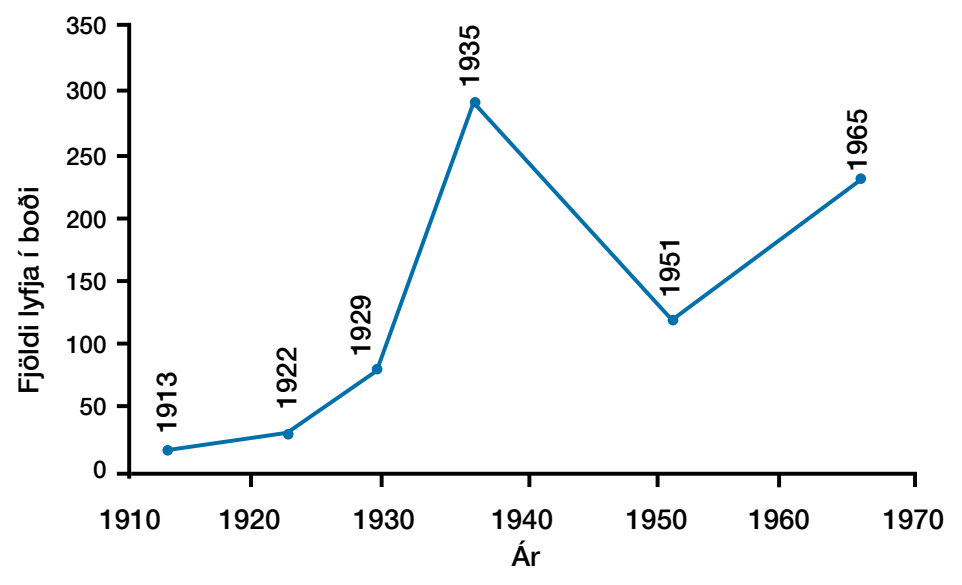

Mynd 9. Fjöldi stungulyfia sem hér var í boði á sex tilgreindum árum á árabilinu 1913-1965, samkvæmt gildandi lyfjaskrám, lyfjaforskriftasöfnum og lyfjaverðskrám og samkvæmt Sérlyfjaskrá 1965. Talning einstakra stungulyfja kann að vera nokkrum vafa bundin og tölur eru poí ekki hárnákvæmar.

skurðaðgerðir og innleiða svæfingu með Evipan - natríum (enhexýmalnatríum) í æð.³ Árið 1946 var prókaín-adrenalín ríkjandi staðdeyfingarlyf á Landakotsspítala, pótt kókaín væri enn notað. ${ }^{44}$ Árið 1951 birtist svo í Læknablaðinu yfirlit yfir svæfingar frá fyrsta svæfingalækninum. Undir lyfjaforgjöf er tíundað ágæti morfíns, atrópíns eða skópólamíns og barbitúrsýrusambanda. ${ }^{45}$ Pegar hér var komið er pví augljóst, að ýmis lyf í formi stungulyfs voru orðin ómissandi við svæfingar eða deyfingar vegna skurðaðgerða.

Pegar Læknablaðið frá priðja og fjórða áratug 20. aldar er skoðað vekja athygli allnokkrar greinar og auglýsingar um meðferðá sýfilis. Vismútstungulyf, til afleysingar á eldri kvikasilfursamböndum, voru kynnt í stuttri grein 1925. ${ }^{46}$ Átta árum síðar lýsti helsti kynsjúkdómalæknir landsins pví að hann hefði á árinu meðhöndlað 20 sjúklinga með

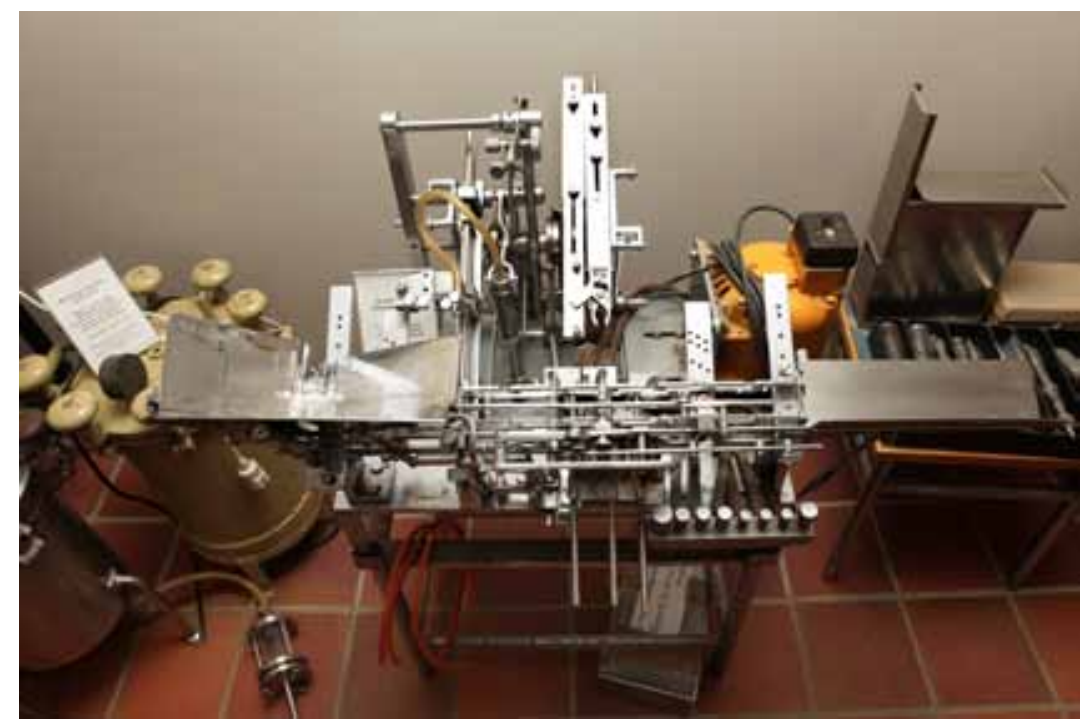

Mynd 10. Myndin sýnir lykjuvél („ampúlluvél”) úr Reykjavíkurapóteki frá stríðsárunum (1942-1943); nokkrar lykjur (,,ampúllur") sjást til vinstri á myndinni. Vélin er nú safngripur i Lyfjafræðisafninu. Porsteinn Scheving Thorsteinsson (1890-1971), lyfsali, innréttaði á árunum 1954-1955 framleiðslueiningu á 4. hæð hússins Austurstrætis 16. Framleiðslu stungulyfja lauk par árið 1990.

(Myndin var tekin í Lyfjafræðisafninu 19. 3. 2010; Forkell porkelsson.) neóarsfenamíni + vismúti. Álagið var pó minna en árið áđur, en pá voru sjúklingarnir ekki færri en $33 .{ }^{47}$ Önnur tegund málmsambanda, lífræn gullsambönd, var á pessum árum reynd gegn berklum, en gafst illa. Hið pekktasta pessara sambanda, natríumárótíómalat, var hins vegar nothæft við iktsýki. Petta var stungulyf til íkomu í vöðva og var auglýst árið 1946 með nafninu Myocrysin ${ }^{\circledR}{ }^{48}$

Insúlín (frá Novo), hið dæmigerða stungulyf, virðist fyrst hafa verið auglýst hér árið 1955. ${ }^{49}$ Tveimur árum síðar er umboðið eftir auglýsingu að dæma komið í hendur Pharmaco hf., Innkaupasambands apótekara, sem pá var nýstofnað. Í pessari sömu auglýsingu eru og kynnt algeng sýklalyf til innstungu (penisillín, streptómýsín). ${ }^{50}$ Pharmaco hf. átti mjög eftir að koma við sögu lyfjaframleiðslu og lyfjaumboða í landinu. Í pessu sambandi vekur pað athygli að stærsta framleiðanda stungulyfja í landinu (ásamt Reykjavíkurapóteki), Lyfjaverslunar ríkisins, sér hvergi stað í auglýsingum Læknablaðsins.

Árið 1940 hefur notkun stungulyfja verið orðin algeng, en jafnframt verið í óviðunandi fari að dómi prófessorsins í meinafræði við Háskóla Íslands. Honum fórust svo orð: „Lyfjadælingar undir hörund, inn í vöðva og æðar, eru orðnar svo algengar á seinni árum, að fjöldi lækna ber dæluna á sér eins og sjálfblekung í vestisvasanum, vanalega fljótandi í vínanda, til að hún sé ávalt dauðhreinsuð til taks, og pannig er lyfjum dælt í hvern sjúkling eftir annan, oft marga á sama klukkutímanum. "51 Hann varaði og lækna við að treysta að fullu á sótthreinsun með etanóli (vínanda) og: „Nota eingöngu soðnar dælur og nálar (10 mín.) og skifta um nál við hvern einstakling. "51 Í ljósi pessara ummæla er alveg tvímælalaust að tilkoma einnota lyfjadæla og nála 20-25 árum síðar hefur verið mikið framfaraskref.

\section{Frambod á stungulyfjum}

Mynd 9 sýnir pann fjölda stungulyfja sem telja má að í boði hafi verið hér á markaði á sex tilgreindum árum á rúmlega 50 ára tímabili (1913-1965).

Árið 1913 voru stungulyf um 20 talsins. Árið 1922 hafði peim einungis fjölgað lítillega (voru um 30 alls). Árið 1929 voru stungulyf sem stóðu íslenskum læknum til boða, talin vera 80. Á næstu árum fjölgaði stungulyfjum mjög og voru árið 1936 orðin um 290 talsins. Stungulyfjum fækkaði aftur og voru um 120 árið 1951. Peim fjölgaði svo enn á ný og voru orðin 230 árið 1965.

Tölurnar frá 1913 og 1922 sýna að stungulyf sem íslenskum læknum stóð pá til boða voru fá. Ætla verður enn fremur að notkun stungulyfja 


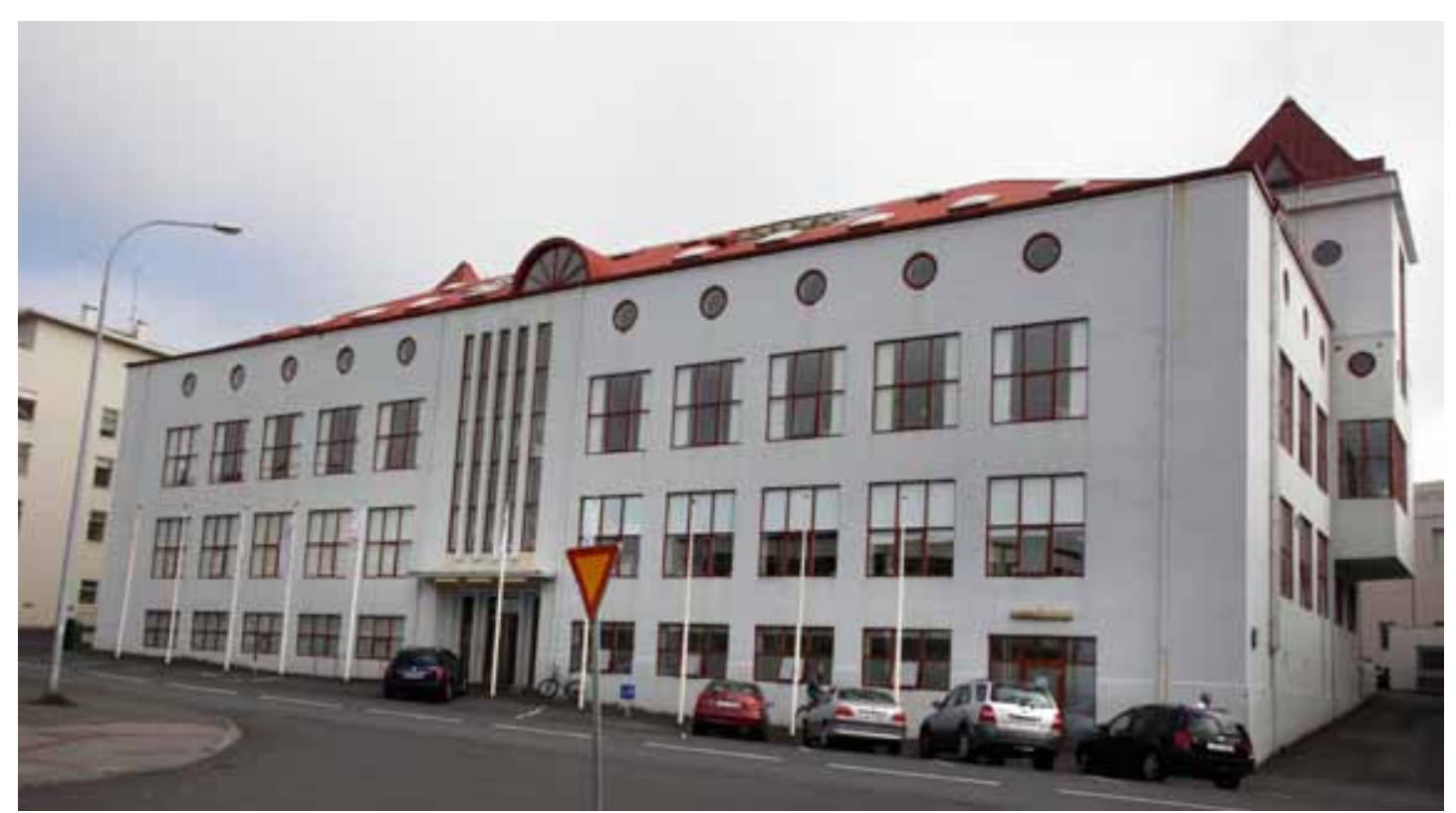

hafi á pessum árum verið lítil í samanburði við pað sem síðar varð. Pá fjölgun sem orðin var árið 1929 er án efa að rekja til innflæðis erlendra sérlyfja á markað hér. Einmitt um petta leyti var fyrst farið að auglýsa lyfjadælur og erlend sérlyf í Læknablaðinu. Trúlega skýrir aukið flæði erlendra sérlyfja á markað einnig pá fjölgun stungulyfja sem greinileg var árið 1936. Lausleg könnun bendir til pess að fjölgun hormónalyfja (kynhormónar), ýmissa miðtaugakerfislyfja og stungulyfja sem notuð eru við svæfingar, svo og staðdeyfingarlyfja geti að talsverðu leyti skýrt pessa miklu fjölgun. Niðursveifla í fjölda stungulyfja sem í boði voru 1951 er óvænt, en vekur jafnframt ýmsar spurningar sem kunna að talsverðu leyti að snúast um pá staðreynd að heil heimsstyrjöld og mjög mikið breytingaskeið var á milli pessara ára. Árið 1965 var svo fjöldi stungulyfja aftur kominn nálega í sama far og var um pað bil 30 árum áður. Рað skal tekið fram að fjöldi einstakra B- og C-vítamínstungulyfja var ætíð lítill, pótt notkun peirra hafi augljóslega verið mikil á tímabili og framleiðsla peirra verið uppistaðan í lyfjagerð flestra lyfjaframleiðenda. Mismunandi fjöldi vítamínstungulyfja skýrir pví ekki pær sveiflur í fjölda stungulyfja sem í boði voru og að framan greinir.

\section{Framleiðsla stungulyfja}

Í spænsku veikinni 1918-1919 var einungis eitt apótek í Reykjavík, Reykjavíkurapótek (á horni Thorvaldsensstrætis og Kirkjustrætis). Af fenginni reynslu taldi bæjarstjórn Reykjavíkur bráða nauðsyn bera til pess að hafa aðra lyfjabúð í bænum. ${ }^{52}$ Pessi lyfjabúð var stofnuð pegar haustið
1919 og var eigandi hennar Stefán Thorarensen (1891-1975). Stefán byggði á fáum árum stórt steinhús yfir lyfjabúðina (og fleiri fyrirtæki) á Laugavegi 16. Stefán sagðist snemma hafa hafið framleiðslu á lyfjum, en lýsti ekki nánar hvaða eða hvers konar lyf hefði verið um að ræða. ${ }^{53}$

Porsteinn Scheving Thorsteinsson (1890-1971) varð lyfsali í Reykjavíkurapóteki sumarið 1919. Porsteinn eignaðist stórhýsið Austurstræti 16 árið 1930 og flutti lyfjabúðina pangað. Næstu tvö apótek í Reykjavík voru stofnuð vorið 1928. Annað var Ingólfsapótek, en hitt Lyfjabúðin Iðunn. Telja verður að öll fjögur gömlu apótekin í Reykjavík (stofnuð fyrir 1930) hafi framleitt stungulyf pegar leið á fjórða tug 20. aldar. Á árunum við upphaf síðari heimsstyrjaldar voru vítamínstungulyf (B- og C-vítamín) mest áberandi í stungulyfjaframleiðslu peirra allra. ${ }^{54}$

Í Reykjavíkurapóteki hafði á pessum árum verið innréttað herbergi sérstaklega fyrir stungulyfjaframleiðslu og par var upphaflega „ampúlluvélin", sem sýnd er á mynd $10 .{ }^{54}$ Á árunum 1954-1955 innréttaði Porsteinn fjórðu hæð húss apóteksins til lyfjaframleiðslu og par á meðal til framleiðslu á stungulyfjum..$^{55}$ Framleiðsla á stungulyfjum í Reykjavíkurapóteki var allstór í sniðum fram eftir árum. Alls voru framleiddar milli 60 og 70 tegundir af stungulyfjum og haft framleidd stungulyf samkvæmt beiðni lækna („ex tempore“). Auk B- og C-vítamína voru par framleidd sæft vatn og saltvatn og stungulyf með cýankóbalamíni (B 12), prókaíni, morfíni, petidíni og teófyllamíni svo nokkur séu nefnd. Pessari framleiðslu lauk um 1990 og hafði árin á undan verið lítil og fyrst og fremst í kennsluskyni. ${ }^{56}$ í birgðum pegar mest var. Par að auki voru
Mynd 11. Borgartún 6 . Dar framleiddi Lyfjaverslun ríkisins innrennslislyf, stungulyf og önnur lyf frá árinu 1954 og til loka sjálfstæðrar starfsemi fyrirtækisins árið 1998 (sbr. texta).

(Myndin tekin íágúst 2010; Borkell porkelsson.) 
Eftir að Stefán Thorarensen stofnaði heildverslun sína árið 1944 fór par fram framleiðsla á stungulyfjum, einkum B- og C-vítamínum, en einnig á öðrum lyfjum. Heildverslunin hafði til umráða tvö sérbúin herbergi í Laugavegsapóteki til framleiðslunnar. Heildverslunin hætti að framleiða stungulyf árið 1972.57 Í Lyfjabúðinni Iðunni var sömuleiðis sérbúið herbergi til stungulyfjaframleiðslu ${ }^{58}$ og að öllum líkindum einnig í Ingólfsapóteki. ${ }^{55}$ Sömu sögu er líklega einnig að segja um næstu fjögur apótek sem stofnuð voru í Reykjavík á árabilinu 1948-1956. Utan Reykjavíkur er höfundum einungis kunnugt um framleiðslu stungulyfja í Hafnarfjarðarapóteki og Stjörnuapóteki á Akureyri.

Lyfjaverslun ríkisins (var upphaflega í Nýborg við Skúlagötu) hafði árið 1950 látið innrétta sérbúin herbergi í íbúđarhúsi til framleiðslu á stungulyfjum. Framleiðsla pessi var smá í sniðum. Árið 1954 fluttist framleiðsla fyrirtækisins í rúm og veglegri húsakynni í Borgartúni 6 (mynd 11). Var par útbúin fyrsta eiginlega smitgátardeild (,,steríl deild“) á Íslandi til framleiðslu á innrennslislyfjum, en einnig stungulyfjum og fleiri tegundum lyfja. Deildin var undir stjórn sérmenntaðs lyfjafræðings, Jóns O. Edwald (f. 1925). Forstjóri Lyfjaverslunarinnar var pá Kristinn Stefánsson (1903-1967), læknir og dósent (síðar prófessor) í lyfjafræði við læknadeild Háskóla Íslands. ${ }^{59-61}$

Framleiðsla Lyfjaverslunar ríkisins miðaðist við parfir spítala, héraðslækna og héraðsdýralækna. ${ }^{59}$ Framleiðsla Lyfjaverslunarinnar á stungulyfjum (og öðrum lyfjum) var stór í sniðum á íslenskan mælikvarða og hélst lengi. Pegar smitgátardeildin hafði verið endurnýjuð eftir bruna árið 1981 fórust tveimur starfsmönnum deildarinnar svo orð: „Lyfjaverslun ríkisins hefur leitast við að búa til pau stungulyf sem beðið hefur verið um svo framarlega sem pað hefur verið framkvæmanlegt við pær aðstæður sem fyrir hendi hafa verið.“62 Lyfjaverslun ríkisins var síðar einkavædd og framleiðsludeild fyrirtækisins innlimuð í annað fyrirtæki.

Pharmaco hf., Innkaupasamband apótekara, var stofnað í febrúar 1956 af sex apótekurum og einum viðskiptamenntuðum manni. Pharmaco hf. varð umsvifamikið lyfjaheildsölufyrirtæki sem flutti inn og seldi mikið af lyfjum, lyfjaefnum og sjúkragögnum. Fyrirtækið hóf árið 1960 framleiðslu á töflum og stungulyfjum í smáum stíl, sem síðar fór vaxandi. Af stungulyfjum bar mest á vítamínstungulyfjum (B- og C-vítamínum), en einnig var talsvert framleitt af petidín- og prókaínstungulyfjum, auk annars. Á árunum kringum 1970 og fyrr leitaði Pharmaco hf. eftir samstarfi við Lyfjaverslun ríkisins eða sameiningu, en úr pví varð ekki. ${ }^{55,63}$

Fyrir gildistöku lyfsölulaga árið 1963 og lengur var öll framleiðsla lyfja hér á landi með viðurkenndum samheitum og samkvæmt almennt gildandi lögbókum - en pær voru nær allar danskar - og tóku til gildandi lyfjaskráa, lyfjaforskriftabóka og annarra lyfjabóka. Мeð lyfsölulögum (og síðari lagabreytingum) fengu sérlyf (proprietary medicines) lagagildi og opn-aðist pá möguleiki til pess að lyfjaframleiðendur gætu fengið lyfjasamsetningar skráðar í Sérlyfjaskrá með sérstöku heiti (sérlyfjaheiti) og í peirra séreign. Pharmaco hf. reið á vaðið með skráningu innlendra sérlyfja í lok áttunda áratugarins. ${ }^{64}$ Forstjóri fyrirtækisins var Steinar Berg Björnsson (f. 1942), sem átti síðar fyrir höndum langt starf á vegum Sameinuðu pjóðanna.

Fyrirtækið Delta hf. var stofnað 1982 út frá Pharmaco hf. og færðist framleiðsluhluti Pharmaco hf. til Delta hf. Delta hf. byggði fullkomna lyfjaverksmiðju í Hafnarfirði árið 1998 og varð stórt fyrirtæki á íslenska vísu og með starfsemi í fjórum löndum. Árið 1998 rann lyfjaframleiðslan (par á meðal stungulyf) sem eftir var í Lyfjaverslun ríkisins (Lyfjaverslun Íslands hf.) inn í Delta hf. ${ }^{60,65}$

Delta og Pharmaco sameinuðust aftur árið 2002 með nafni Pharmaco. Er talið að í pví fyrirtæki hafi framleiðslu stungulyfja á Íslandi endanlega lokið árið 2003 - og lýkur par með pessari sögu. Að lokum má nefna að árið 2004 varð hið nýja Pharmaco að Actavis sem nú er risastórt fyrirtæki en lýtur stjórn erlends manns og í raun einnig erlends banka. ${ }^{64,66,67}$

\section{Lokaorð}

Alexander Wood fann hvorki upp lyfjadælu né holnál. Uppruni pessara hluta virðist vera í nokkurri óvissu. Hlutur Fergusons skurðlæknis sem upphafleg dæla og nál Woods voru kennd við, hlýtur pó að vera mikill. Vægi Woods fólst öðru fremur í pví að hann lagaði bæði lyfjadælu og nál að klínískri notkun og innleiddi með pví auðvelda aðferð til pess að koma lyfjum undir húð, í vöðva eða í æð.

Próun stungulyfja og aðferða við notkun peirra var í takt við aukna vitneskju á öðrum sviðum, ekki síst lífeðlisfræði og örverufræði og par með talið sæfing og sótthreinsun. Ef horft er um öxl má samt undrast hve seint læknar virðast almennt hafa tekið upp fullnægjandi sótthreinsun á dælum og nálum áður en einnota lyfjadælur og holnálar komu á markað upp úr miðri 20. öld. Ritgerð Níelsar Dungal frá $1940^{51}$ er til vitnis um petta. 
Morfín sem var fyrsta lyfið er dælt var í hold sjúklinga er enn í fullu gildi. Verður tæpast bent á nokkurt annað lyf sem hefur haldið gildi sínu svo vel og lengi. Raunar töldu læknar lengi vel að morfín gefið undir húð ylli ekki ávana og fíkn, pótt ópíum um munn gerði pað. Af ritgerð Allbutts frá $1870^{26}$ (og viðauka við hana) má skilja að misnotkun morfíns af völdum lækna hafi víða verið alvarlegt vandamál á síðari hluta 19. aldar. Ætla má pó að pessa hafi ekki gætt hér á landi vegna pess hve íslenskir læknar tóku almennt seint að nota lyfjadælur og holnálar við lækningar.

Prentaðar heimildir um stungulyf eða notkun peirra á Íslandi hafa ekki fundist fyrr en nálgast tekur aldamótin 1900. Pessu til stuðnings er að lyfjadælur og holnálar hafa væntanlega ekki verið til í helsta spítala landsins árið $1878 .{ }^{12}$ Ekki er petta síst athyglisvert vegna pess að peir prír læknar (Jón Hjaltalín, Tómas Hallgrímsson, Jónas Jónassen) sem báru uppi kennslu við Læknaskólann frá upphafi 1867 og fram yfir 1890, voru allir menntaðir utan landsteinanna. Tveir peirra voru að auki læknar við aðalspítala landsins. Skurðlækningar í nútímaskilningi námu hér land á síðasta tug 19. aldar og upp úr aldamótunum 1900. Leiddi pað án efa smám saman til aukinnar notkunar á verkjadeyfandi lyfjum til innstungu. Ný staðdeyfingarlyf (í stað kókaíns) ruddu sér og til rúms í byrjun 20. aldar og síðar. Ef dæma má af peim heimildum sem fyrir liggja um fjölda stungulyfja hér á markaði, hefur pessi próun pó verið ærið hæg (mynd 9). Skýrslur spítala eru ótrúlega fáorðar fram eftir árum um notkun stungulyfja og geta varla um notkun annarra lyfja en svæfingarlyfja og staðdeyfingarlyfja. Skýrslur spítala hafa pvíi í heild lítið heimildagildi um notkun stungulyfja á pví tímabili er hér um ræðir.

Auglýsingar hafa talsvert heimildagildi um pað sem auglýst er. Pví er pað í ljósi sögunnar mjög bagalegt að Lyfjaverslun ríkisins skyldi aldrei auglýsa stungulyf né önnur lyf og pað engu síður pótt til pess gætu hafa legið gild rök. Ein fyrsta auglýsing ótvírætt um stungulyf í Læknablaðinu (um norskt sérlyf með morfínlíka verkun) er frá árinu 1932.68 Sú auglýsing, ásamt fyrstu auglýsingum um lyfjadælur og holnálar nokkru fyrr, ${ }^{14,}{ }^{15}$ benda eindregið til pess að breiðari markaður stungulyfja hafi pá verið að verða til. Раð styður ennfremur pessa ályktun að mikil fjölgun stungulyfja hér á markaði varð á árunum 1929-1936 (mynd 9). Engin augljós skýring er hins vegar á fækkun stungulyfja árið 1951 í samanburði við árið 1936.

Athygli vekur hve mörg apótek framleiddu stungulyf á árabilinu frá ca. 1940-1970. Í pennan flokk bættust prjár lyfjagerðir og heildsölur. раð vekur jafnframt athygli að burðarásinn í framleiðslu nær allra pessara fyrirtækja voru Bog C-vítamínstungulyf. Pau framleiddu einnig flest eða öll prókaínstungulyf. Einungis tveir stærstu framleiðendurnir, Reykjavíkurapótek og Lyfjaverslun ríkisins, buðu upp á stórt úrval stungulyfja. Heimildir um innlenda framleiðslu stungulyfja eru af skornum skammti. Samt má ætla að framleiðsla B- og C-vítamínstungulyfja (og prókaínstungulyfja) hafi á tímabili verið sérlega arðbær (vegna mikillar notkunar?), en sá hagnaður síðar horfið og par með sá grundvöllur sem verið hafði til framleiðslu á stungulyfjum eða jafnvel öðrum lyfjum í lyfjabúðum. Auknar kröfur til lyfjagerðar hafa og án efa skipt verulegu máli. Skömmu áđur en lyfjaframleiðslu lauk í Reykjavíkurapóteki voru pessi mál skoðuð með formlegum hætti par. Niðurstaðan var einföld: Framleiðsla lyfja með sama hætti og verið hafði stóð ekki undir sér. Apótekið treysti sér heldur ekki til að verða við auknum kröfum um góða framleiðsluhætti á lyfjum (,,Good pharmaceutical manufacturing practice“). ${ }^{69}$ Pótt pessi staða sé uppi um framleiðslu á stungulyfjum eða á öðrum lyfjum í lyfjabúðum, kann annað að gilda um framleiðslu lyfja á vegum ríkisins í ljósi sérstöðu lyfjamarkaðar og peirrar fákeppni sem hér ríkir.

раð er viðurkennt að hefðbundin markaðslögmál gilda ekki nema að litlu leyti á lyfjamarkaði. Petta mótast af pví að sá sem ávísar lyfjum (læknir) parf ekki að greiða pau, og sá sem notar lyfin (sjúklingur), parf að jafnaði einungis að greiða pau að hluta (30-40\%), en ríkissjóður greiðir meirihlutann. ${ }^{70}$ Pví er pað illskiljanlegt að ríkissjóður skyldi einkavæða Lyfjaverslun ríkisins og flytja með peirri ákvörðun sem næst alla framleiðslu á stungulyfjum (eða öðrum lyfjum), sem teljast samheitalyf (lyfjasamsetningar, sem ekki eru varðar einkaleyfum upphafslegs framleiðanda) á hendur eins framleiðanda, Actavis. Par á ofan hefur pessi framleiðandi nánast ákvörðunarvald um pað hvort lyf séu framleidd í landinu eða ekki og getur í krafti stöðu sinnar ráðið lyfjaverði eins og bent hefur verið á. ${ }^{71}$

\section{Pakkarorð}

Heimildamönnum, sem auðkenndir eru með fæðingarári í heimildaskrá, er pakkað peirra framlag. Dr. Kristínu Björgu Guðmundsdóttur, dýralækni, Tryggva Ásmundssyni, lækni, og Werner Rasmussyni, fyrrum lyfsala, eru færðar pakkir fyrir að lesa yfir handritið og gagnrýna. Önnu Porbjörgu Porgrímsdóttur, Lækningaminjasafninu, er pakkað fyrir að leyfa 
birtingu á myndum af lyfjadælum sem eru í safninu (myndir 2 og 3). Porkeli Porkelssyni M.A., ljósmyndara, er pakkað fyrir töku mynda 4-7 og 1011. Védísi Skarphéðinsdóttur, ritstjórnarfulltrúa, eru færðar pakkir fyrir lán á mynd 8 og aðstoð við endanlegan frágang á handriti. Gömlum samstarfsmanni okkar, Jóhönnu Edwald, er pökkuð aðstoð við gerð prenthandrits.

\section{Heimildir}

1-40. Sjá fyrri hluta greinarinnar. Læknablaðið 2011; 97: 101-7.

41. Jónsson V. Lækningar og saga. Tíu ritgerðir. Síðara bindi. Bókaútgáfa Menningarsjóðs, Reykjavík 1969: 538, 687, 758.

42. Jónsson V. Lækningar og saga. Tíu ritgerðir. Fyrra bindi. Bókaútgáfa Menningarsjóðs, Reykjavík 1969: 378-443.

43. Einarsson M. Nokkur orð um deyfingar. N2O narcosis Evipan - Natr. Narc. intravenosa. Anæsthesia - spinalis. Í Skýrslu St. Jóseps spítala 1934:16-28.

44. Einarsson M. Appendectomiae 1908-1946. Í: Skýrslu um St. Jóseps spítala í Reykjavík 1946:30-7. [Fyrstu botnlangaskurðaðgerðir á Íslandi voru gerðar 1902 og 1903].

45. Eyvindsson E. Um svæfingar. Læknablaðið 1951; 36: 33-44

46. Benediktsson J. Vismuth við syfilis. Læknablaðið 1925; 11: $57-8$.

47. Guðmundsson H. Morbi venerei í Reykjavík árið 1933. Læknablaðið 1934; 20: 33-6.

48. Auglýsing um Myocrysin ${ }^{\circledR}$ (lausn í lykjum) frá Stefáni Thorarensen hf. Læknablaðið 1946; 31 [aftan við meginmál 10. heftis]

49. Auglýsing um insúlínsamsetningar (frá Novo) frá Reykjavíkurapóteki. Læknablaðið 1955; 39 [aftan við meginmál 1. heftis].

50. Auglýsing um insúlínsamsetningar (frá Novo) frá Pharmaco hf. Læknablaðið 1957; 41. [aftan við meginmál 1.-2. heftis].

51. Dungal N. Slys af lyfjadælingum. Læknablaðið 1940; 26 $40-3$.
52. Jóhannesson P. Pankabrot um spánsku veikina 1918-1919. Læknablaðið 2008; 94: 766-72.

53. E. B. Kandídat klippti asperínskammta allan daginn. Viðtal við Stefán Thorarensen apótekara. Tímarit um lyfjafræði 1972; 7: 46-8.

54. Edwald E (f. 1921,fyrrum lyfsölustjóri); uppl. jan. 2010 [var lærlingur í Reykjavíkurapóteki 1940].

55. Rasmusson W (f. 1931, fyrrum apótekari); uppl. 6. 5. 2010 [var nemi í Reykjavíkurapóteki 1953].

56. Magnússon E (f. 1949, skrifstofustjóri í heilbrigðisráðuneytinu); uppl. 20. 5. 2010 [hafði umsjón með lyfjaframleiðslu í Reykjavíkurapóteki 1975-1990].

57. Sigurðsson B (f. 1935), Jónsson B (f. 1942) og Guðmundsson GV (f. 1941) (lyfjafræðingar); uppl. mars 2010 [störfuðu á mismunandi tímum hjá Stefáni Thorarensen].

58. Einarson B. Jóhanna Magnúsdóttir. Minning. Tímarit um lyfjafræði 1981; 16:140-1.

59. Edwald E. Um Lyfjaverslun ríkisins. Tímarit um lyfjafræði 1982; 17: 71-7.

60. Jóhannesson P. Úr sögu innrennslislyfja á Íslandi með ívafi eigin minninga og brotlegrar minjavörslu. Læknablaðið 2006; 92: 328-33

61. Lyfjaverzlun ríkisins tekur í notkun nýja fullkomna vinnustofu. Albýðublaðið 6.11.1954.

62. Sveinsson Á, Edwald JO. Framleiðsla stungu- og dreypilyfja. Tímarit um lyfjafræði 1981; 16: 94-6.

63. Tíminn 16.12.1976. Frétt (frá blaðamannafundi).

64. Guðmundsdóttir KB (f. 1962); uppl. 26.2. og 22.6.2010 [starfsmaður Actavis hf.]

65. Guðmundsdóttir J. Delta hf. 20 ára. Tímarit um lyfjafræði 2002; 37: 8 .

66. Sameining Delta og Pharmaco. Gögn frá Actavis 22.6.2010.

67. Höfuðstöðvar Actavis verða fluttar til útlanda. Morgunblaðið (Viðskiptablað) 24.6.2010.

68. Auglýsing um "Nyco"-præparater (frá Sv. A. Johansen). Læknablaðið 1932; 18 [á titilörk janúar-febrúarheftis].

69. Magnússon J, Magnússon E. Reykjavíkur apótek. Athugun á framtíðarmöguleikum nýrrar framleiðsludeildar (skýrsla). 1989 (50 bls., 2 viðaukar)

70. Samkeppnisstaða íslensks lyfjaiðnaðar. Iðnaðar- og viðskiptaráðuneyti 1998: Rit 98-4.

71. Hauksson SR. Sinadráttur og gróðafíkn. Fréttablaðið 27.7.2010.

\section{Injection medicines: Historical notes on their use and development, with special reference to Icelandic conditions}

The first reliable syringes and hollow needles for the injections of drugs subcutaneously, intramuscularily and intravenously or for other injections came into use shortly after 1850. As far is known, morphine was the first drug to be injected subcutaneously, using a syringe and a hollow needle. Use of injection medicines, especially containing morphine or other alkaloids, became widespread among European doctors in the latter half of the 19th century. The use of injection medicines began before the existence of infectious microbes or microorganisms in general had become common knowledge, or the equilibria of electrolytes in and around living cells had been understood. Thus, injection medicines, their production and procedures of use had to pass through lengthy development lasting nearly one hundred years, in order to reach the

Key words: syringes, needles, injections, medicines, drugs. levels of quality standards now universally accepted. It was also a definite advancement when disposable syringes and needles came into general use around 1960. Accessibility to injection medicines and their use was seemingly on a low scale in Iceland until 1930 or thereabout. The production of injection medicines in Iceland began in substance in the fourth decade of the last century. The production was generic, following official formulas, and was based in several pharmacies and a few drug companies. Only two producers offered a sizeable assortment of drugs. The production gradually became concentrated in a few firms and was finally handled by only one international, locally based, generic drugs firm, where the domestic production of injection medicines ended shortly after 2000. 